\begin{tabular}{|l|l|l|l|}
\hline Eiszeitalter u. Gegenwart & 29 & $\begin{array}{c}189-200 \\
7 \mathrm{fig} .\end{array}$ & Hannover 1979 \\
\hline
\end{tabular}

\title{
Remarks on the Genesis of Subglacial Channels in Northern Poland
}

\author{
Upper Pleistocene, channel, fluviatile erosion, glacial erosion, glacier, glacial lake \\ NW-Polish Lowlands
}

Michą Pasierbski *)

Abstract: The origin of the majority of subglacial channels and similar valleys in Nothern Poland, taking in account their character and differenciated shape (narrow, deep, long and curved) is connected with erosional activity of subglacial waters.

But the author based on several examples shows, that some of these channels have a more combined genesis, when the main factor has been the inland ice (narrow, small ice tongues).

\section{[Zur Genese subglaziärer Rinnentäler im nördlichen Polen]}

Kurzfassung: Die Entstehung der meisten subglaziären Rinnentäler sowie ähnlicher Talformen in Nordpolen wird ihrer Eigenschaften wegen (eng, tief, lang und gewunden) allgemein mit der Erosionstätigkeit der subglazialen Wässer in Verbindung gebracht.

Der Verfasser zeigt an ausgewählten Beispielen, daß ein Teil dieser Rinnentäler eine mehrfach kombinierte Entstehung aufweist, wobei als Hauptagens schmale und kleine erodierende Eisloben infrage kommen.

S t reszczenie: Geneza większości rynien subglacjalnych oraz dolin o podobnym charakterze w Polsce Północnej, biorąc pod uwagę ich zróżnicowany kształt (wąskie, głębokie, długie i kręte) uważana jest powszechnie jako wynik erozyjnej działalności wód subglacjalnych.

Autor w oparciu o wybrane przykłady wykazuje, że niektóre z tych rynien mają bardziej złożoną genezę, gdzie głównym czynnikiem w ich formowaniu ostatecznego ksztaltu był lądolód (wąskie, małe loby lodowcowe).

\section{Preface}

Subglacial channels are landforms characteristic of a glacial environment, they occur in areas of ground moraines and outwashes as well as of end moraines, and they cut across pradolinas and fluvial valleys. Also characteristic is that as rule they run parallel to each other. Where they meet an obstruction they either end their run, or they keep going merely changing their direction. Sometimes they appear in a fan-like pattern, showing differences in widths and changes in depths, it also happens that such channels cross each other at various angles. The floor relief of the subglacial channels is ragged and uneven, their long profiles show numerous steps and overdeepenings, these latter filled with lake water. Near the inland ice margin the subglacial channels break off, ending their run, this feature GaLON (1965) considers evidence of the farthest extent of the Last Glaciation.

After Majdanowski (1950) the subglacial channels occur in highest concentration in the end moraine zone, next come moraine plateaus while outwash sheets reveal differences in channel density. Whereas all characteristic features of subglacial channels are

Address of the author: Dr. M. P a s i e r b sk i, Dep. of Geogr. Nicholas Copernicus University, ul. Fredry 8. 87-100 Toruń, Poland. 
known for a long time, the problem of their origin continues to be one of the moot points lacking a satisfactory explanation in glacial environment, and therefore is often the object of controversies.

Evolution of opinions about the origin of subglacial channels

The oldest concept of how such channels may have developed was what was called the "tectonic concept" at that time put forward by BERENDT (1863). Several years later BERENDT (1879) took it for granted that these channels had originated in ice crevasses as the effect of meltwater action. Next it was JenTzSCH (1884) in whose belief these channels were of subglacial origin, and in his opinion the direction of subglacial streams might often have been independent of the direction in which the ice was moving.

In Kozarski's (1966/7) opinion JentzsCH came very near to introducing hydrostatic pressure into the process of channel formation, but finally it was Ussing (1903), and after him WERTH (1907), who took this stand. In this matter uncommonly important were the observations made by Ussing. On Jutland this scientist observed a close interrelation between subglacial channels and the starting points of outwash sheets issuing from channel outlets in the shape of widespread cones. Ussing's discovery of this recurrence became an important element in controversies about the erosive character of subglacial channels. The problematics introducted by Ussing were later considerably expanded and documented by WerTH $(1908 / 9)$.

A separate page in investigations of subglacial channels refers to research work by WOLDSTEDT $(1923,1926,1952,1954)$. Initially he was in full accord with Ussing's (1903) and Werth's (1908/9) opinions, trying to suplement them by his own field work in the northern parts of Germany and Poland. However, gradually WOLDSTEDT come to prefer a different concept: he assumed that part of the subglacial channels those of considerable width, may have originated from the erosive action of glacier lobes. This explains why in 1929 he maintained that any sort of channels formation is connected with glacial erosion, this belief he kept up until 1952, with the definite assertion that in the area of the Last Glaciation the subglacial channels have resulted from an erosive action of the inland ice, while not disputing some co-action of meltwater streams in this process, he emphasized that their part used to be limited to the initial stage of dissection of the substratum which, subsequently, was sculptured by the inland ice. In his field examinations WOLDSTEDT used to scrutinize the widely radiating end depressions known from the Alpine foreland. In his attempt of discerning resembling examples in lowland areas he discovered similarities in the Odra lobe where he believed the channels of the Prenzlau and the Randow rivers as well as the valleys of the lower Odra and of Lake Miedwie to have been sculptured by the action of narrow glacial lobes. In addition WoLDSTEDT indicated examples from North America (Lake Michigan), from the Baltic basin and from Fennoscandia where he also believed the channels to have developed due to glacial erosion. However, some vacillation in what he used to believe can later be observed in WolDSTEDT's book "Das Eiszeitalter" published in 1954, where he speaks less decisively about the glacial origin of subglacial channels.

WOLDSTEDT's concepts gained both supporters and opponents. One of the former who took up and pursued this concept was JASPERSEN (1953) who during his field studies on the Cymbrian peninsula attempted to apply to further areas the results he observed here. Also a follower of a glacial origin of the channels seems to have been LIEDTKE (1975). This scientist, commenting upon Ussing's (1903) suggestions about the close relations of outwash sheets to glacial channels, arrived at the conclusion that outwash sheets do not 
always have to be connected with glacial channels. As an example he indicates the $700 \mathrm{~km}$ part of a Pomeranian end moraine where outwash plains cover as much as $650 \mathrm{~km}$ while the area of a ground moraine is limited to $50 \mathrm{~km}$. This evidence made him assume that glacial channels were by no means the only source that used to supply the sandy deposits forming outwash plains. An additional argument put forward by LiedTKe (1975), incidentally endorsing WOLDSTEDT's concept, is the presence of steps in the subglacial channels, he compares them with similar steps observed in fiords and Alpine valleys. Furthermore LIEDTKE calls attention to another of his observations: how the subglacial channels grow more narrow and less deep where they approach the line of the inland ice margin. In his opinion, the geomorphological action of water should be most effective at places where subglacial waters issue, therefore here the channels should be deepest. Notwithstanding all the above arguments, LIEDTKE also perceived other evidence that contradicts a glacial origin of the channels, such as: their winding run, their fan-like pattern, and other details. Ultimately he admits this problem to be a difficult one, and that in deliberating about the origin of the channels mainly into account should be taken: glacial erosion, erosion by subglacial waters, partly also specific tectonics even processes of salt leaching causing the formation of initial depressions. He advises that, up to the time a definite explanation of the origin of these channels is secured, they should be called glacial channels.

In Polish literature Woldstedt's opinions were taken up by KondRacki (1965) in whose belief the channel dimensions (their considerable widths) preclude assuming them to have originated from an erosive action of flowing water. On the other hand KOZARSKI $(1966 / 7)$ insists, that only a minor part of the channels observed in Poland and in the German Plain may have been formed by glacial erosion. He feels unable to agree with WoLDSTEDT's concepts in their full scope, because in his own opinion most of the channels are small and run in a winding course, and near glacitectonic disturbances they are altogether lacking. Authors like Nechay (1932), Majdanowsin (1950), Galon (1965) and others agree in their publications that the principal agent forming these channels must have been meltwater streams. Even so, this in no way precludes the possibility that the channels might have been secondarily transformed by narrow glacier lobes. Examples of such processes, though but few, are known from literature (GALON 1952; Roszkó WNA 1964; Kozarski 1965; PASIERbSki 1973, 1975).

As can be seen, this brief survey of relevant literature discloses that, outstanding and constantly recurring in controversies about the origin of the channels, are two concepts in which the main agent is either glacial erosion or erosion by subglacial waters. However, it should be kept in mind that often these two processes were superimposed upon each other, that one may have cleared the way to the other, and conversely.

Area of research

In the present study the author purposely selected such channels in Northern Poland whose features admitted the assumption that they have resulted from the co-action of glacial lobes and relief made it possible to correlate them with landforms classical in this respect, such as the Tollense-See Becken (JANke 1961) and the Malchiner Becken (REINHARD \& RICHTER 1958), but where definite geological evidence was lacking. Worth mentioning are: 1. the channel of Zarnowieckie Lake, 2. the channel of Charzykowy Lake, 3. the channel of Lake Miedwie (Fig. 1). 


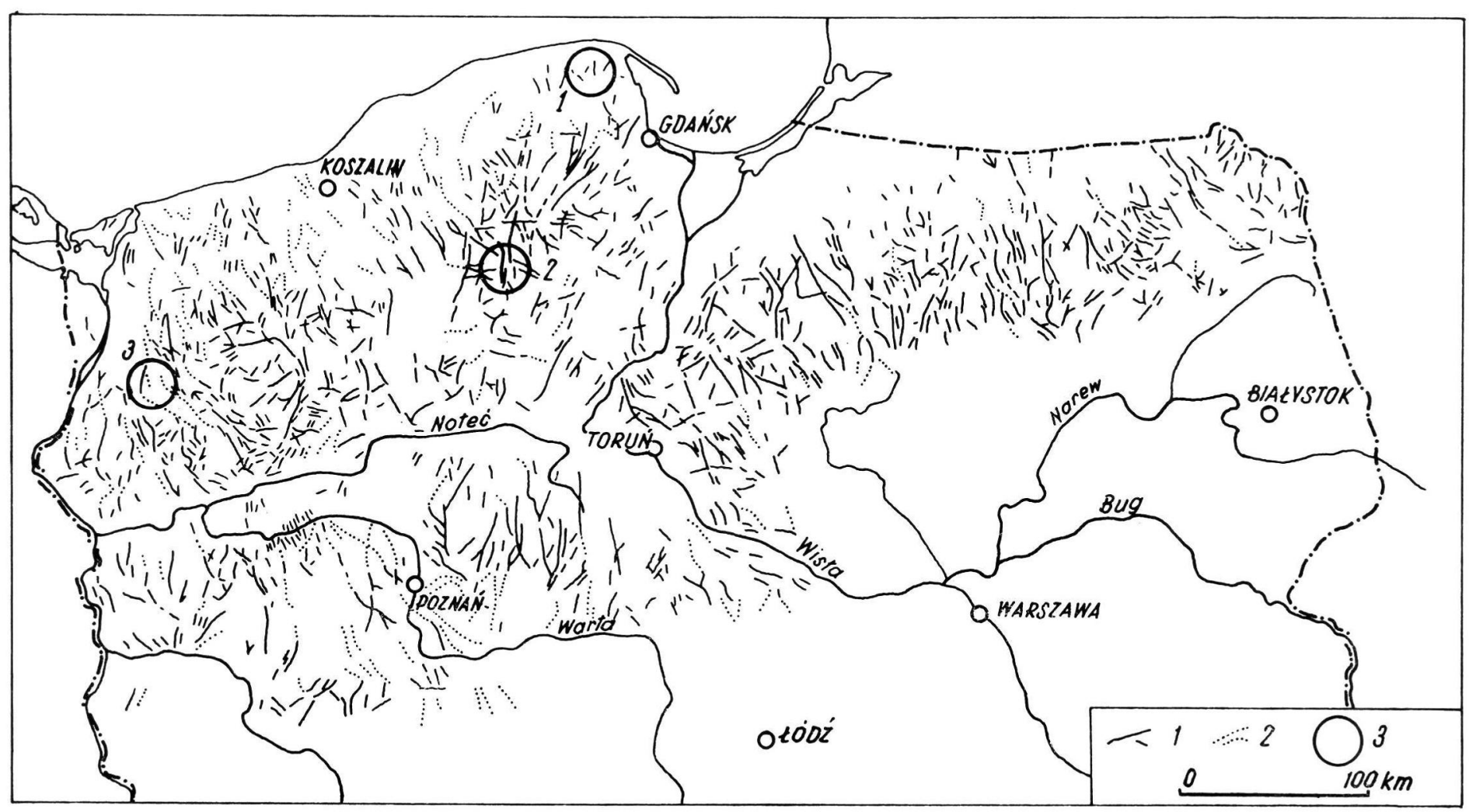

Fig. 1: Subglacial channels of the last glaciation in Poland (after GaLON 1972). 1. subglacial channels; 2 . subglacial channels transformed by rivers; 3 . areas discussed by the author. 


\section{The channel of Żarnowieckie Lake}

Situated fairly close to the Baltic shore this channel passes two genetically divergent geomorphological units: a moraine plateau and an accumulation lowland. The length of this channel is some $12 \mathrm{~km}, 2 / 3$ of which is occupied by Żarnowieckie Lake. In its northern part where the two geomorphological units adjoin each other, the channel is widest, up to about $3 \mathrm{~km}$, in southward direction it grows narrower to about $2 \mathrm{~km}$ and at the channel outlet a radial system of channels can be obserwed that bears features different from those described above. Along both slopes of the channel the moraine plateau rises to $110 \mathrm{~m}$ a.s.l., further on subsiding gradually some $40 \mathrm{~m}$ - seemingly this is the picture of an asymetrical ridge surrounding the channel from east and west. The considerable difference between the surface of the moraine plateau and the water level in the lakeamounting to $80-100 \mathrm{~m}-$ led to heavy dissection of the channel scarps by rainfall and groundwater. Żarnowieckie Lake occupies almost the whole width of the channel, its floor is level constituting what is called a cryptodepression. It was probably the shape of the channel and of elevation surrounding the channel that made SonNTAG (1911) put forward his thesis that an arch of end moraines is surrounding the channel, and that these end moraines are the result of a dilation of the channel by a narrow glacial lobe. To some extent SonNTAG's opinion was criticized by PAWŁOWsKI (1922) and, later on, by ZABORSKI (1933). Both disputed the existence of an end moraine arch surrounding the lake; after ZABORSKI these elevations were formed by some dilation of the channel by a glacier lobe, but to him they do not bear the features of end moraines. Later on this opinion was also upheld by Roszkówna (1964) who reports successive stages of formation and decay of the glacier lobe and indicates that drainage used to proceed here in southward direction.

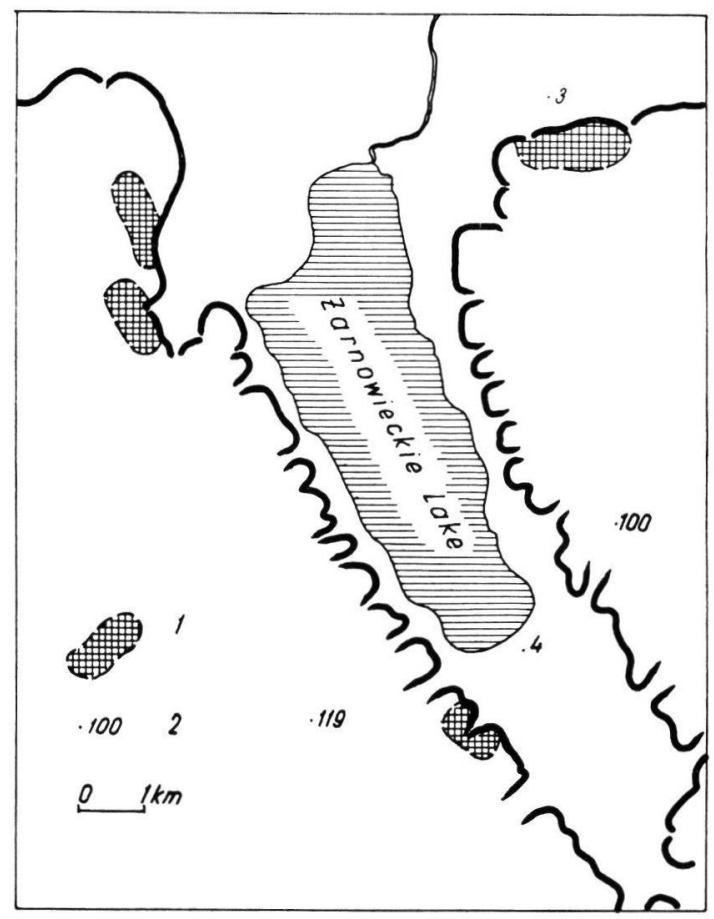

Fig. 2: Areal distribution of floes of Tertiary deposits around of Zarnowieckie Lake. 1. floes of Tertiary deposits; 2 . altitudinal points. 
Field investigations carried on by the present author in the spring of 1977 revealed on the fringe of the coastal lowland and in the vicinity of the channel the presence of Miocene floes in the Quaternary deposits (Fig. 2). Furthermore, a detailed analisis of the geological structure, downward from the surface of the moraine plateau to the channel bottom, disclosed glacitectonic disturbances of an asymmetrical type; upright folds, and horizontal shifting of strata (Fig. 3). Most distinctly visible were these phenomena halfway down the channel scarp, further down they are concealed by sandy deposits, which here form narrow level of kame terrace.

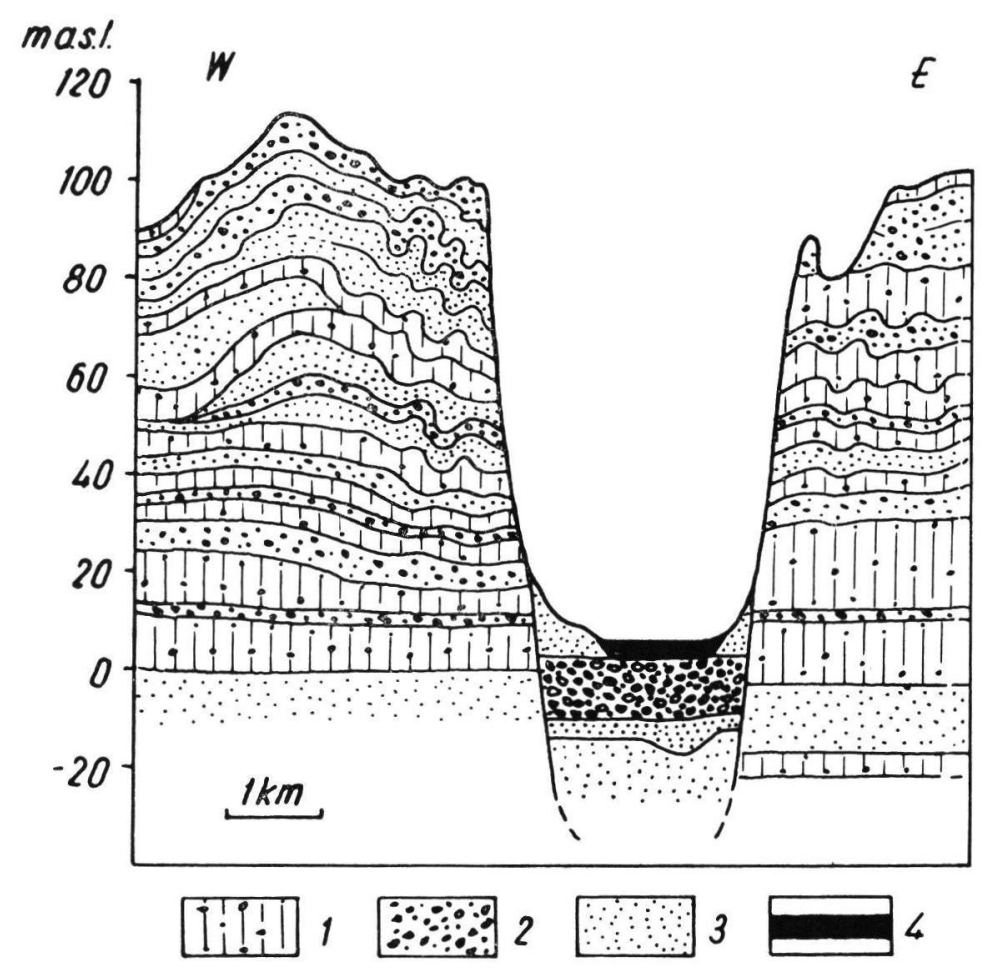

Fig. 3: Simplified geological section across of the Żarnowiec channel. 1. boulder clay; 2. sands and gravels with boulders; 3 . sands; 4 . peat.

The presence of floes as well as the discovery of glacitectonic structures in the channel entourage constitute the missing link among testimonies for a glacial origin of the Żarnowieckie Lake channel. This confirms how correct was SonNTAG's (1911) concept and the opinions of ZABORSKI (1933) and Roszkówna (1964) as well, all of whom contemplated this problem by keeping geomorphological elements in mind. The analysis of the local geological structure indicates in the substratum of the channel the existence of a fossil valley of considerable depth, because in the axis of this valley all glacial deposits have been destroyed. This observation is in so far essential as it shows the part played by depressions and by valleys running parallel with the direction of advancing inland ice, they facilitated differences in the rate of the ice motion within the zone of the ice margin, and in consequence led to the formation of glacier lobes of different sizes. 


\section{The channel of Charzykowy Lake}

Situated where the Brda outwash plain and the Krayna Plateau are in contact, this channel runs in N-S direction and in its length of $17 \mathrm{~km}$ shows a considerable width, from 2 to $2,5 \mathrm{~km}$. The southern bank of the channel, incised in a moraine plateau, is enclosed by an asymmetrical arch of end moraines, creating the impression of a widespread amphitheatre. The eastern wing of this arch is rather indistinct due to the presence there of many narrow channels extending at different elevations; in their pattern they resemble a fan issuing from outlet of the charzykowy channel. Both the shape and the pattern of the subglacial channels which occur here in a fairly dense network, with N-S, NW-SE and NE-SW directions prevailing clearly indicate their being of an older age then the wide charzykowy channel which - although seemingly it may have developed from one of the subglacial channels - its present-day appearence is definitely due to the erosive action of a narrow glacier lobe (Fig. 4). By the way, this author has been voicing this same opinion at an earlier date while studying the geological structure of this region (Pasierbski 1975).

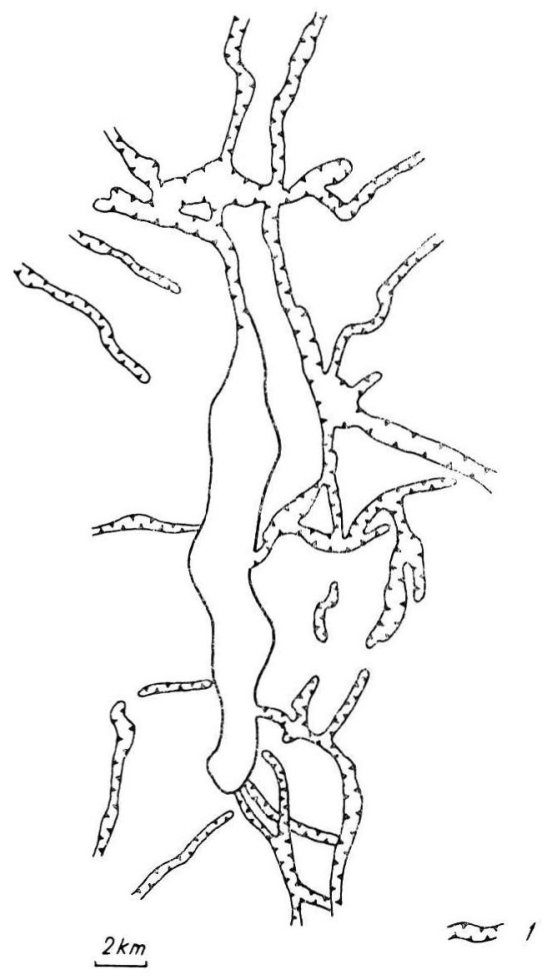

Fig. 4: Arrangement and width of subglacial channels in comparison with Charzykowy Lake basin. 1. subglacial channels.

In their majority the subglacial channels of the Krayna Plateau are narrow, winding and very deep. Some of than dissect the Quaternary deposits to such extent that their bottoms lie often in Miocene deposits. Under the lacustrine and outwash deposits appears in the charzykowy channel the boulder clay of the Poznan Stage (Frankfurt) (Fig. 5). This boulder clay appears also in the southern bank of the channel where it is spread over some glacitectonically upthrusted sands and gravels. 


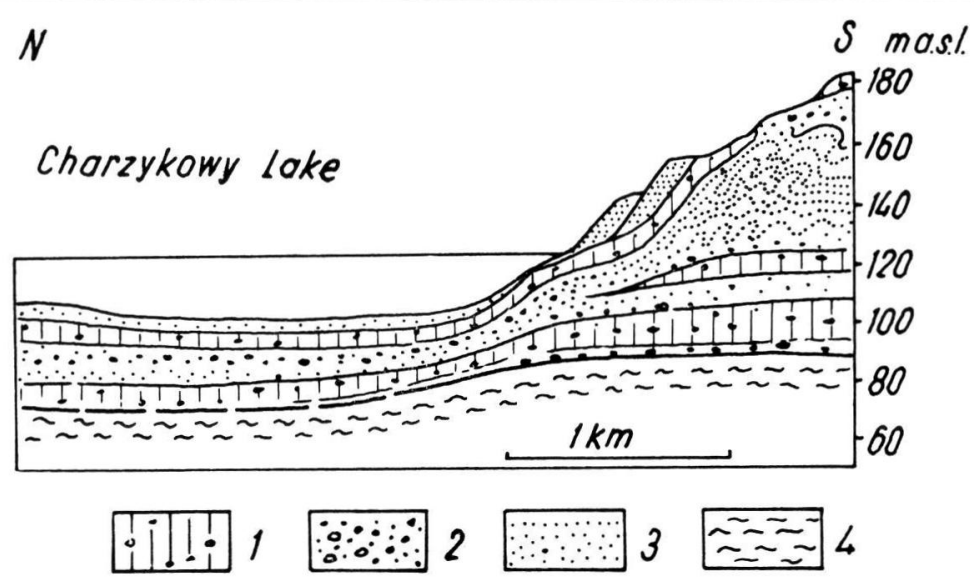

Fig. 5: Simplified geological section across of the south part of the Charzykowy Lake. 1. boulder clay; 2 . sands and gravels; 3 . sands and silts; 4 . Miocene deposits.

\section{The channel of Lake Miedwie}

Situated in the central part of the Odra lobe and extending in $\mathrm{N}-\mathrm{S}$ direction, this channel is the largest among those described so far. Its length is about $20 \mathrm{~km}$. Its mean width $2,5 \mathrm{~km}$, though in the southern part the width exceeds $4 \mathrm{~km}$ (Fig. 6). The first to point out the glacial character of this channel was WoLDSTEDT (1952) who ascribed a similar origin to the valleys of the lower Odra, the Prenzlau and the Randow also. Later on KARCZEWSKI (1965) established, while studying the geomorphology of the Pyrzyce Lowland that the channel of the Lake Miedwie has been formed by a narrow glacier lobe and in supporting this assertion he indicates the ridges of upthrusted end moraines flanking the southern and southeastern bank of the channel, he even enters these ridges in his map. However, three years later KARCZEWSKI (1968) changes his view point regarding the origin of the channel of Lake Miedwie, by assuming that the basin of Lake Miedwie and the whole channel had once been filled by dead ice. As proof of this assumption he mentions the occurrence of settling structures in the ice-dammed deposits. Morever he belives, that also the steep deep of the strata observed in the upthrusted end moraines and the presence of highly fissil boulder clay may be evidence of the settling which followed the dead ice melting.

The interpretation suggested by KARCZEWSKI (1968) contains some inaccuracies. East of Lake Miedwie the Pyrzyce Lowland where he distinguished a set of levels, shows a diversified relief and often boulder clay can be seen on its surface - a fact not mentioned by KARCZEWSKI. The rims of these levels are indistinct and often they simply pass into each other. The moraine plateau, studded with drumlins, part of which KARCZEwSKI (1965) at least believes to be of erosive origin, differs in no way from the ground level adjoining it. Next to the drumlins occur esker ridges both on the plateau and on the highest level of the Pyrzyce Lowland. The close vicinity of these two landforms reveals that they were formed during different periods the drumlins while the area suffered glaciation, the esker during deglaciation. Put together, these few remarks combine into a logical total indicating the erosive origin of this part of the Odra lobe. The pattern in which the drumlins and the narrow subglacial channels running parallel with the drumlins seem to prove their being of identical age. On the other hand the wide channel occupied by Lake Miedwie is here of later age, a secondary formation, the southward extension of this channel can be traced beyond the Odra lobe, but here it turns irregular and winding. 


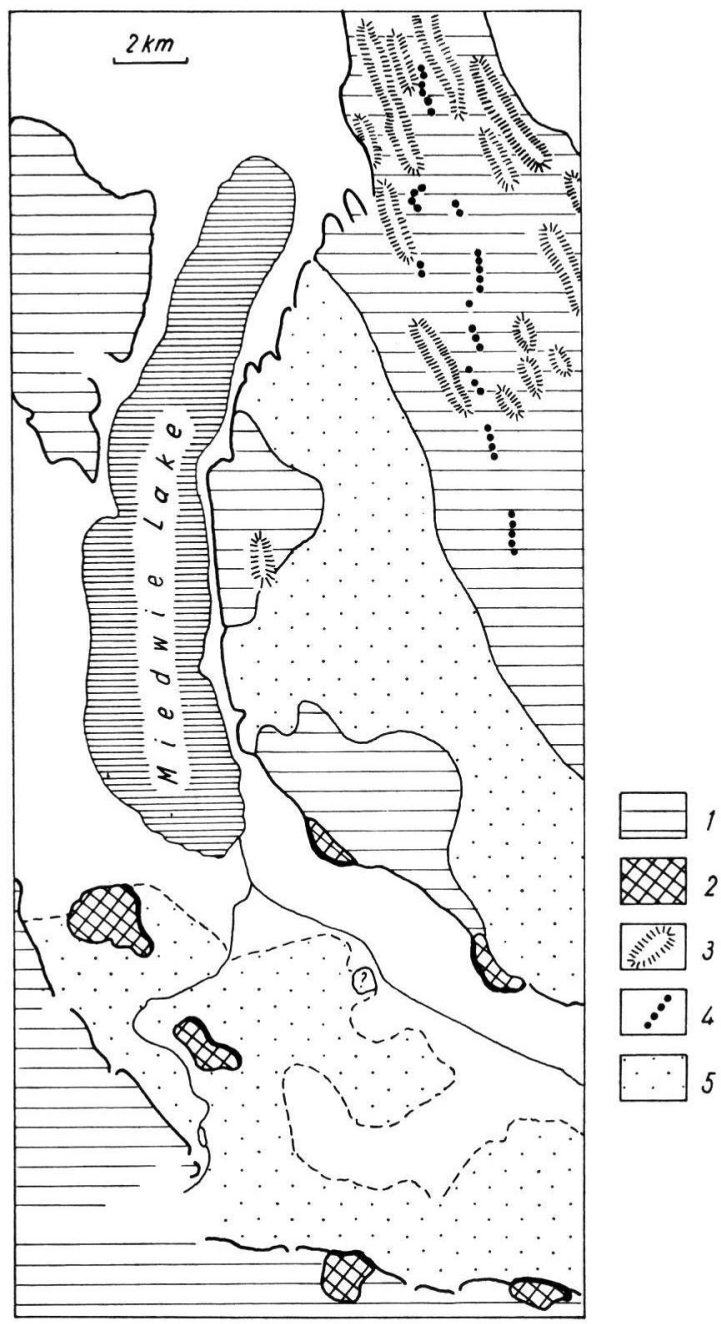

Fig. 6: Geomorphologic outline of Miedwie Lake surroundings (partly after KarczewsKi 1965). 1. moraine plateau; 2. end moraines; 3 . drumlins; 4. eskers; 5. levels of Pyrzyce ice-dammed basin.

The examination of the geological structure of vicinity of Lake Miedwie discoloses marked divergences in the altitude of the Tertiary which rises to particular heights some $7 \mathrm{~m}$ below ground surface as much as along the western bank of the channel. This high position of the top of the Tertiary and the differences in the Quaternary deposits along the eastern and western side of the channel (Fig. 7) imply the past occurrence of glacitectonic disturbances. Considering in addition the upthrusted end moraines observed by KARCZEWSKI which by no means fortuitously surround archlike the southern rim of the channel, it clearly appears that this valley is following the line of a subglacial channel developed, in consequence of the erosive action of a narrow glacier lobe.

Apart from the above described channels whose glacial origin is unquestionable, there can be observed quite a number of others in Nothern Poland which not only on account 


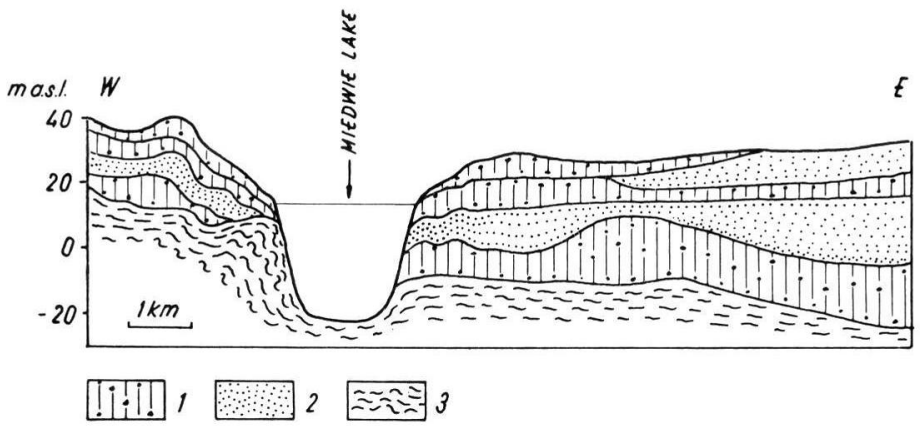

Fig. 7: Simplified geological section across of the Miedwie Lake. 1. boulder clay; 2. sands; 3. Miocene deposits.

of their shape and their size can be looked upon as subglacial in origin. Worth mentioning among them is the kikolska channel situated on the Dobrzyń Plateau, some time age described by NeCHAY (1927), the channel of Kreqpskie Lake on the Krayna Plateau, as well the channel issuing from the drumlin field near Zbójno investigated by NIEwIAROwSKI (1957). Most of these channels are marked by drumlins showing a upthrusted interior structure. Notwithstanding the fact these channels are by means wide, the very presence of drumlins is apt to indicate their origin.

\section{Conclusions}

The development of investigations and polemic which since a long time deal with the origin of the subglacial channels is constantly yielding additional facts broadening our knowledge. However, there continue to be a number of open questions lacking explanation which ultimately solved, may prove correct either one of the concepts under deliberation.

The analytical study of the pattern and the distribution of channels in Northern Poland (Fig. 1) indicate that in their vast majority these landforms are short. Apart from few exceptions, their direction is always perpendicular to the line in which the inland ice margin came to rest. The result of this rule is a spatial difference in the run of the channels in the areas of particular glaciation stages (Brandenburg, Frankfurt, Pomeranian). Even so, there are certain directions in common for all stadials - showing that these channels did outlive the stadials. What then are they really. Replicas of ice crevasses, or of the results of glacial erosion?

1. If glacial erosion has taken place, glacitectonic structures should be in evidence along the channels. Yet observations known so far indicate that in the end moraines adjoining the channels glacitectonic disturbances have been occuring at low depths, from 0 to $5 \mathrm{~m}$ only below the ground surface, while farther down the deposits lie conformably (PAsierbski 1973). The channel bottoms are incised much deeper.

2. Investigations of channels producted by narrow glacier lobes indicate, that they are widened sections of subglacial channels. They occur at certain places only, in spite of the run of the channel continuing to be visible. 
3. The numerous transverse steps observed in the channels show features of accumulation (GALON 1965; KozARsKi 1966/7).

4. Difficult to ascribe to glacial erosion are the areally very small but exceptionally deep kettles which occur in the channel.

\section{Bibliography}

Berendt, G. (1863): Die Diluvialablagerungen der Mark Brandenburg, insbesondere der Umgebung von Potsdam. - 85 S., Berlin (Mitter u. Sohn).

- (1880): Gletschertheorie oder Drifttheorie in Norddeutschland. - Z. dt. geol. Ges., 31: 1-20; Berlin.

Galon, R. (1952): O fazach postoju lądolodu na obszarze Pomorza. - Księga Pam. 75-lecia Tow. Nauk. w Toruniu. 49-59 p.; Toruń.

- (1965): Some new problems concerning subglacial channels. - Geogr. Pol., 6: 19-28; Warszawa.

GRIPP, K. (1964): Erdgeschichte on Schleswig-Holstein. - 411 p.; Neumünster (Wachholtz).

JANKE, W. (1961): Entstehung und Formenwelt des Naturschutzgebietes Nonenhof. - Naturschutzarbeit in Mecklenburg. 4: 108-118; Berlin.

JASPersen, P. (1953): Sanderbildung durch subglaziäre, aufsteigende Schmelzwasserströme? Eiszeitalter u. Gegenwart, 3: 129-135; Öhringen/Württ.

Jentzsch, A. (1884): Úber die Bildung der preußischen Seen. — Z. dt. geol. Ges., 10: 699-702; Berlin.

Karczewski, A. (1965): Z zagadnień geomorfologicznych Niziny Pyrzyckiej. - Bad. Fizjogr. n. Polską Zach., 15: 71-89; Poznań.

- (1968): Wpływ recesji lobu Odry na powstanie i rozwój sieci dolinnej Pojezierza Myśliborskiego i Niziny Szczecińskiej. (Summery: Influence of the Odra lobe recession uppon the origin and development of the valleys net of Myślibórz Lakeland and Szczecin Lowland). Pozn. Tow. Przyj. Nauk. Prace Kom. Geogr. Geol., 8: 105 p.; Poznań.

Kondracki, J. (1965): Geografia fizyczna Polski. - 575 p.; Warszawa.

Kozarski, S. (1965): Zagadnienie drogi odpływu wód pradolinnych w zachodniej części pradoliny Noteci-Warty. (Summary: The problem of outflow way of pradolina waters from the west part of Noteć-Warta pradolina.) - Pozn. Tow. Przyj. Nauk, Prace Kom. Geogr. Geol., 5: 98 p.; Poznań.

- (1966/7): The origin of subglacial channels in the North Polish and North German Plain. Bull. de la Soc. des Amis des Sci et des Lettres de Poznań, 20: 21-36; Poznań.

Liedtke, H. (1975): Die nordische Vereisung in Mitteleuropa. - 160 p., Bonn.

Majdanowski, S. (1950): Zagadnienie rynien jeziornych na Niżu europejskim. (Summary: The problem of lake-channels in the European Plain.) - Bad. Fizogr. nad Polską Zach., 2: 35116; Poznań.

Nechay, W. (1927): Utwory ladowcowe Ziemi Dobrzyńskiej. - Spraw. Panstw. Inst. Geol., 4: 61-144; Warszawa.

- (1932): Studia nad genezą jezior Dobrzyńskich. (Résumé: Etudes sur la genese des lacs de Dobrzyń.) - Przegl. Geogr., 12: 124-177; Warszawa.

Niewiarowski, W. (1957): Wybrane zagadnienia z bedań geomorfologicznych na arkuszu Mazowsze. - Dok. Geogr., 3: 24-37; Warszawa.

PasierbSKI, M. (1973): Przebieg deglacjacji i formy terenu północnej części Wysoczyzny Krajeńskiej. (Summary: The course of deglaciation and the landforms in the northern part of Krayna Plateau.) - Stud. Soc. Sci. Torunensis. Geogr. et Geol., 8: 99 p.; Warszawa.

- (1975): Uwagi o genezie niecki Jeziora Charzykowskiego. (Summary: Remarks on the genesis of the Charzykowy Lake basin.) - Acta Univer. Nicolai Copernici Geogr., 11: 101-113; Poznań. 
PAwŁowskı, S. (1922): Charakterystyka morfologiczna wybrzeża polskiego. - Poz. Tow. Przyj. Nauk., 2: 19-117; Poznań.

Reinhard, H. \& Richter, G. (1958): Zur Genese der Gletscherzungenbecken Norddeutschlands. Z. Geomorph., 2: 55-75; Berlin.

Roszkowna, L. (1964): Z morfogenezy okolic Jeziora Zarnowieckiego. (Summary: On the morphogenesis of the surroundings of Zarnowiec Lake.) - Zesz. Nauk. UMK. Geogr., 3: 73-83; Poznań.

SonntaG, P. (1912): Der Żarnowitzer See und sein Moränenkranz. - Schr. d. Natur-Ges., 13: 152-163; Gdańsk.

Ussing, N. V. (1903): Om Jyllands Hedesletter og Theorierne om deres Dannelse. - K. dansk. Vidensk. Selsk. Forhandl., 2: 99 p.; Københaven.

Werth, E. (1907): Studien zur glazialen Bodengestaltung in den skandinavischen Ländern. Z. Ges. Erdk., 27: 17-41; Berlin.

- (1908/9): Fjorde, Fjaerde und Föhrden. - Z. Gletscherk., 2: 346, Berlin.

Woldstedt, P. (1923): Studien an Rinnen und Sanderflächen in Norddeutschland. - Jb. Preuss. Geol. L.-Anst., 42: 780-820; Berlin.

- (1926): Probleme der Seebildung in Norddeutschland. - Z. Ges. Erdk., 2: 103-124; Berlin.

- (1952): Die Entstehung der Seen in den ehemals vergletscherten Gebieten. - Eiszeitalter u. Gegenwart, 2: 146-153; Öhringen/Württ.

- (1954): Das Eiszeitalter. Bd. I - 374 p., Stuttgart (Enke).

ZABORSKI, B. (1933): Zarys morfologii północnych Kaszub. — Inst. Bałt., 56 p.; Toruń. 